EXTENDED REPORT

\title{
Influence of format on in vitro penetration of antibody fragments through porcine cornea
}

\author{
H M Brereton, S D Taylor, A Farrall, D Hocking, M A Thiel, M Tea, D J Coster, K A Williams
}

Br J Ophthalmol 2005;89:1205-1209. doi: 10.1136/bjo.2005.066225

See end of article for authors' affiliations

......................

Correspondence to:

Dr Keryn Williams,

Department of

Ophthalmology, Flinders

Medical Centre, Bedford

Park, SA 5042, Australia;

keryn.williams@flinders.

edu.au

Accepted for publication 1 March 2005

\begin{abstract}
Aim: Antibody fragments, appropriately formulated, can penetrate through the ocular surface and thus have potential as therapeutic agents. The aim was to investigate the influence of protein fragment format on the kinetics and extent of ocular penetration in vitro.

Methods: Immunoglobulin single chain variable domain fragments of a murine monoclonal antibody with specificity for rat CD4 were engineered with a 20 or 11 amino acid linker by assembly polymerase chain reaction, expressed in Escherichia coli and purified by chromatography. Fab fragments of the parental antibody were prepared by papain digestion. Antibody fragments were formulated with a penetration and a viscosity enhancer and were applied to the surface of perfused pig corneas for up to 10 hours in vitro. Penetration was quantified by flow cytometry on rat thymocytes.

Results: 20-mer antibody fragments formed natural monomers and dimers following purification that could be separately isolated, while 11-mer fragments were dimeric. All formats of fragment (20-mer monomers and dimers, 11-mer dimers, Fab) showed penetration through the pig cornea after 6 hours of intermittent topical administration.

Conclusion: Antibody fragments of different shapes and sizes can penetrate the cornea after topical administration, thereby increasing the potential of this class of proteins for topical ophthalmic use.
\end{abstract}

$\mathrm{T}$ pical application is the preferred method of adminis tration of drugs to the cornea and anterior segment, because therapeutic concentrations can often be achieved without systemic side effects. Furthermore, self administration of eye drops can be managed by many patients. However, topical treatment will only be of therapeutic use if the drug can penetrate through the ocular surface.

The corneal epithelium, stroma, and endothelium all form barriers to intraocular drug penetration. In particular, the intercellular tight junctions of the most superficial epithelial cells provide an effective seal. ${ }^{2}$ Hydrophilic drugs penetrate corneal epithelium by diffusion through small pores within the tight junctions of these cells. ${ }^{3}$ The pore size has been calculated to be $2-3 \mathrm{~nm}$ in diameter and drug penetration through these pores is strongly size dependent. ${ }^{45}$ The intercellular spaces between basal and intermediate epithelial cells are wider, allowing penetration of hydrophilic molecules with a molecular weight of at least 40 kiloDalton $(\mathrm{kDa}){ }^{2}$ Lipophilic drugs readily penetrate the epithelial surface via a transcellular pathway, ${ }^{6}$ in a process that is independent of molecular size. ${ }^{1}$ The cut-off size for penetration through the corneal stroma has been estimated as being approximately $500 \mathrm{kDa},{ }^{7}$ although the actual level may be much lower. ${ }^{1}$ The hydrophilic corneal stroma forms a weak barrier for lipophilic drug penetration. ${ }^{6}$ The corneal endothelium forms another barrier for hydrophilic drugs especially, but the tight junctions are incomplete, ${ }^{8}$ allowing penetration of molecules up to approximately $60 \mathrm{kDa} .^{9}$ Drug penetration through sclera is very similar to penetration through corneal stroma. ${ }^{1}{ }^{10} 11$

Penetration of hydrophilic drugs through the conjunctiva greatly exceeds penetration through the cornea. ${ }^{4}$ Dextran-20 $(20 \mathrm{kDa})$ can penetrate the normal conjunctiva without a penetration enhancer. ${ }^{12}$ Up to half of any topically applied low molecular weight drug is absorbed through the conjunctiva into the subconjunctival connective tissue, ${ }^{13}{ }^{14}$ and thence into a dense net of blood and lymph vessels before they reach the sclera. ${ }^{75} 16$ The conjunctival/scleral route contributes little to intraocular bioavailability of small drugs that penetrate the cornea well, but may contribute substantially to intraocular penetration of hydrophilic drugs with limited corneal permeability. ${ }^{17}{ }^{18}$ In addition, there is a well recognised limbal absorption route, where drugs penetrate the permeable conjunctiva before entering the eye through the corneal stroma. ${ }^{19}$

Immunoglobulins (Ig), and particularly secretory IgA, are constituents of the tear film, and form part of the defence mechanisms of the outer eye. However, antibodies are too large to penetrate the cornea rapidly. ${ }^{9}$ Single chain variable domain antibody fragments ( $\mathrm{scFv}$ ) lack the constant region domains of whole antibodies and are relatively small (28 kDa monomers). ${ }^{20}$ Such fragments can penetrate tissues efficiently when administered systemically, and have considerable therapeutic potential. ${ }^{21}{ }^{22}$ We recently demonstrated that scFvs can penetrate across the cornea when applied topically in vitro and in vivo. ${ }^{23}$ We have now identified methods that allow the separation of various monomeric and dimeric fragments of a particular antibody (fig 1), and show that fragments of several different shapes and sizes can penetrate the perfused pig cornea in vitro.

\section{MATERIALS AND METHODS}

Production and purification of engineered antibody constructs

Single chain variable domain fragments $(\mathrm{scFv})$ were generated from log phase cultures of the OX38 hybridoma, producing mouse anti-rat CD4 IgG2a antibody, ${ }^{24}$ by the method of Krebber et al. ${ }^{25}{ }^{26}$ ScFv constructs with 20 amino acid (20-mer) and 11 amino acid (11-mer) linker sequences were generated in the pHB400 vector which incorporates a poly-histidine sequence. ${ }^{27}$ Following fermentation in 15 litre batches, Escherichia coli extracts were treated with 1\% Triton

Abbreviations: Ig, immunoglobulins; IMAC, immobilised metal affinity chromatography; $\mathrm{MFI}$, mean fluorescence intensity; scFv, single chain variable domain antibody fragments 

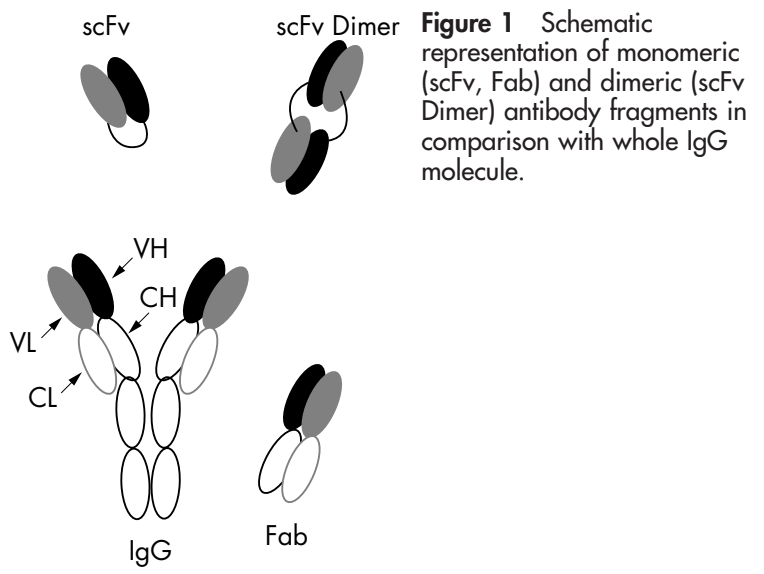

X-100 to reduce endotoxin, ${ }^{28}$ and purified on a Ni-NTA (Qiagen, Clifton Hill, VIC, Australia) column $(10 \times 10 \mathrm{~cm})$ by elution with a linear imidazole gradient $(20-500 \mathrm{mM}){ }^{26}$ Fractions containing scFv were pooled and further purified using a Q Sepharose HP (Amersham Biosciences, Sydney, Australia) anion exchange column $(6 \times 10 \mathrm{~cm})$. Bound scFv was eluted stepwise with $50 \mathrm{mM}$ and $70 \mathrm{mM} \mathrm{NaCl}$. Purified antibody fragments were concentrated using Macrosep centrifugal concentrators (Pall Gelman Laboratory, Sydney, Australia), filter sterilised and stored at $4^{\circ} \mathrm{C}$. Endotoxin levels were measured by Limulus Amoebocyte lysate test (Charles River Laboratories, Wilmington, MA, USA).

\section{Preparation and purification of Fab fragment}

OX38 IgG was purified from hybridoma culture supernatant by Protein-A chromatography and digested using papain agarose (Sigma-Aldrich, Sydney, Australia). ${ }^{29}$ Fab fragments were purified on a Q Sepharose HP column and eluted with a linear $\mathrm{NaCl}$ gradient $(0-1 \mathrm{M}){ }^{30}$

\section{Determination of antibody fragment purity and molecular weight}

Purity of antibody fragments was determined using SDSPAGE analysis. Relative molecular mass of each antibody fragment fraction was estimated using a Superdex 75 HR 10/ 30 size exclusion column calibrated with gel filtration standard proteins (Bio-RAD, CA, USA). The molecular weights of Fab and scFv monomers were determined using electrospray ionisation mass spectrometry (ESI-MS).

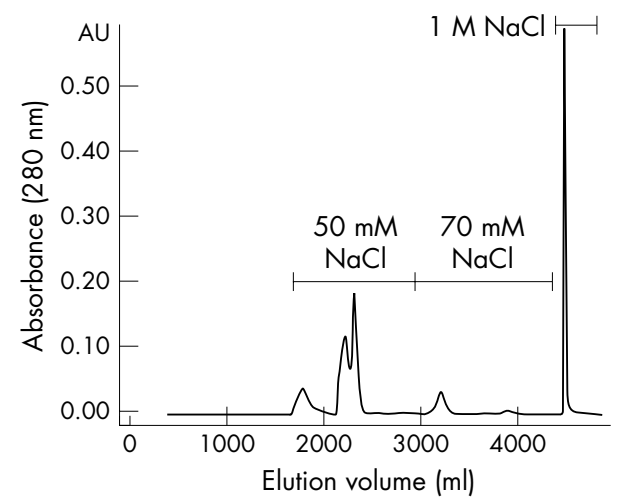

Figure 2 Anion exchange elution profile of 20-mer scFv. Stepwise elution separated monomeric scFv, dimeric scFv and contaminants. The $50 \mathrm{mM} \mathrm{NaCl}$ step eluted three peaks containing monomeric scFv. The $70 \mathrm{mM} \mathrm{NaCl}$ step eluted dimeric scFv and $1 \mathrm{M} \mathrm{NaCl}$ eluted scFv complexed with contaminant protein.
Formulation of antibody and antibody fragments for topical application

Control eye drops comprised OX38 hybridoma culture supernatant containing IgG at a concentration detectable at a dilution of $\mathrm{l}$ in 30000 by flow cytometry. Antibody fragments were prepared at $2-10 \mathrm{mg} / \mathrm{ml}$ protein in $10 \mathrm{mM}$ HEPES buffer $\mathrm{pH} 7.5,150 \mathrm{mM} \mathrm{NaCl}$. The protein concentration was the maximum achieved for each fragment preparation and was governed by fragment solubility. Just before the experiment, the solution was diluted $1: 1$ with $1 \%$ capric acid sodium salt (Sigma-Aldrich) as a penetration enhancer and 3\% hydroxypropyl methylcellulose (Dow Chemical Pacific Ltd, Marleston, SA, Australia) as a viscosity enhancer in $10 \mathrm{mM}$ HEPES buffer $\mathrm{pH} 7.5,150 \mathrm{mM} \mathrm{NaCl}{ }^{23}$

\section{Corneal perfusion}

Normal pig corneas were prepared and immediately mounted in a polycarbonate and stainless steel corneal perfusion chamber, which has been described in detail previously. ${ }^{31}$ One $50 \mu \mathrm{l}$ drop of antibody fragment formulation was applied topically to the corneal surface every 20 minutes over the time course of the experiment. Every hour, $220 \mu \mathrm{l}$ of the perfusate was removed from the perfusion reservoir for testing, and replaced with the same volume of fresh BSSPlus. ${ }^{23}$ The condition of the corneas was monitored hourly using a hand held ultrasonic pachymeter (Biovision Pocket pachymeter, BV International, Clermont-Ferrand, France).

\section{Measurement of antibody and antibody fragment concentration}

Binding activity of OX38 antibody and antibody fragments to normal rat thymocytes was measured by flow cytometry as described previously. ${ }^{23}{ }^{32}$ For whole IgG and Fab fragment the incubation with anti-PolyHis antibody was omitted. All assays were performed in duplicate and variation was routinely less than $10 \%$. Mean fluorescence intensity (MFI) was used as a relative quantitative measure for antibody or antibody fragment concentration after penetration through the cornea, by comparison with titration series of known purified protein concentrations.

\section{Conventional histology}

Corneoscleral buttons were fixed in $10 \%$ buffered formalin in PBS, paraffin embedded, sectioned at $10 \mu \mathrm{m}$ and stained with Mayer's haematoxylin and eosin.

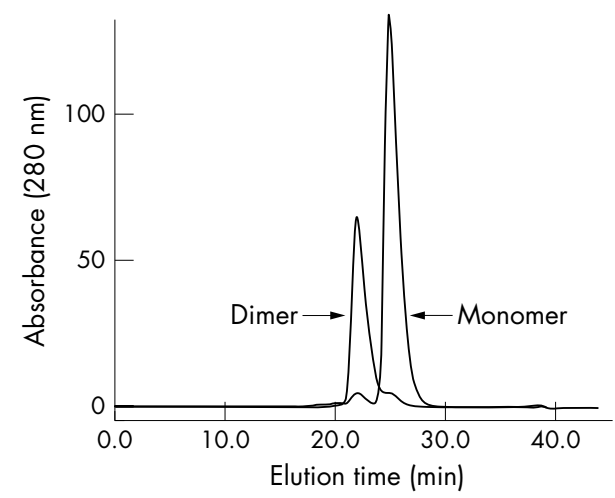

Figure 3 Size exclusion chromatography on a calibrated Superdex 75 $10 / 30$ column. Overlay of representative chromatograms of purified monomeric and dimeric 20-mer scFv. Monomer eluted at 25 minutes and dimer at 22 minutes. The elution times are consistent with calculated molecular masses of $27 \mathrm{kDa}$ and $56 \mathrm{kDa}$ respectively. 
Table 1 Antibody fragment yield, purity, and endotoxin contamination following purification (SD)

\begin{tabular}{lllll}
\hline Fragment & $\mathbf{M W}^{*}(\mathbf{k D a})$ & $\begin{array}{l}\text { Yield from 15 litre } \\
\text { ferment }(\mathbf{m g})\end{array}$ & Purity & Endotoxin (EU/mg protein) \\
\hline ScFv 20-mer (monomer) & 27 & $145(32)$ & $>95 \%$ & $<0.5$ \\
ScFv 20-mer (dimer) & 56 & $18(4)$ & $>95 \%$ & $<0.5$ \\
ScFv 11-mer (dimer) & 52 & $52(4)$ & $>95 \%$ & $<0.5$ \\
Fab (monomer) & 48 & NAt & $>91 \%$ & $<0.2$ \\
\hline
\end{tabular}

*Determined by size exclusion chromatography.

†NA = not applicable: yield of Fab following digestion and purification was $80 \%$.

\section{RESULTS}

\section{Purification of antibody fragments}

A purification procedure was designed to separate monomeric and dimeric antibody fragments of high purity with low levels of endotoxin. His tagged scFvs were captured from bacterial homogenates using immobilised metal affinity chromatography (IMAC). A single peak was eluted from the IMAC column and the purity of $\mathrm{SCFV}$ was approximately $57 \%$. Anion exchange chromatography further reduced endotoxin contamination and stepwise elution separated monomeric and dimeric 20-mer scFvs (fig 2). The $50 \mathrm{mM}$ $\mathrm{NaCl}$ step eluted three peaks. Size exclusion chromatography showed that all peaks contained predominantly monomeric scFv $(>90 \%)$ with an estimated molecular mass of $27 \mathrm{kDa}$. The $70 \mathrm{mM} \mathrm{NaCl}$ step eluted a single peak containing predominantly dimeric scFv (94\%) with an estimated molecular mass of $56 \mathrm{kDa}$ (fig 3). The same purification process was used for the 11-mer construct and produced only dimeric scFv with an estimated molecular mass of $52 \mathrm{kDa}$. Fab fragments, purified by anion exchange chromatography, were monomeric with an estimated molecular mass of $48 \mathrm{kDa}$. The monomeric molecular masses of the 11-mer scFv, 20-mer scFv and Fab were verified by ESI-MS to be $27410 \mathrm{Da}, 27982 \mathrm{Da}$, and $49046 \mathrm{Da}$ respectively. Evaluation by size exclusion chromatography showed that monomeric and dimeric scFv preparations were stable for at least 6 months. Purification yields, purity and endotoxin levels of the purified fragment preparations are shown in table 1 .

Penetration of antibody fragments across the cornea Purified protein of each antibody fragment prepared in an aqueous formulation containing $0.5 \%$ sodium caprate to

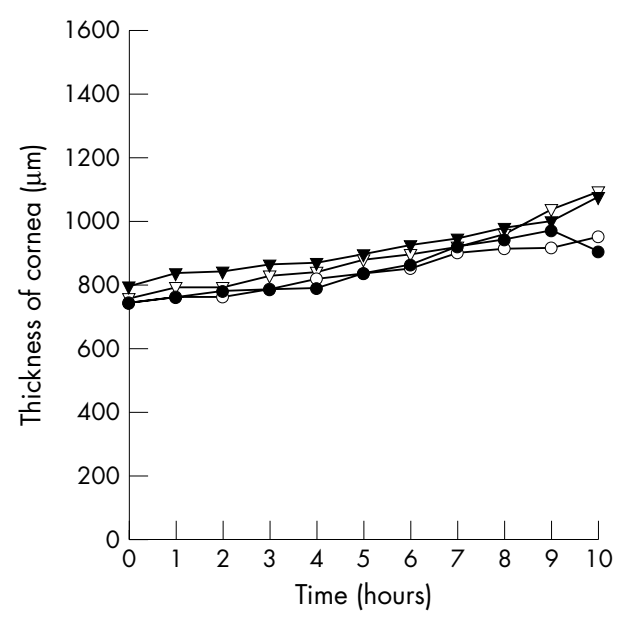

Figure 4 Representative pachymetry on four pig corneas perfused for 10 hours. Each cornea was treated topically with a different formulated antibody fragment. Corneal thickness increased gradually by approximately $30 \%$ over the 10 hour observation period. enhance penetration and $1.5 \%$ hydroxypropyl methylcellulose to increase viscosity was applied topically to the surface of pig corneas mounted horizontally in a corneal perfusion chamber. One $50 \mu \mathrm{l}$ eye drop containing $0.8-5.2 \mathrm{mg}$ protein/ $\mathrm{ml}$ was applied to each cornea thrice hourly for a period of 10 hours. The thickness of corneas typically increased
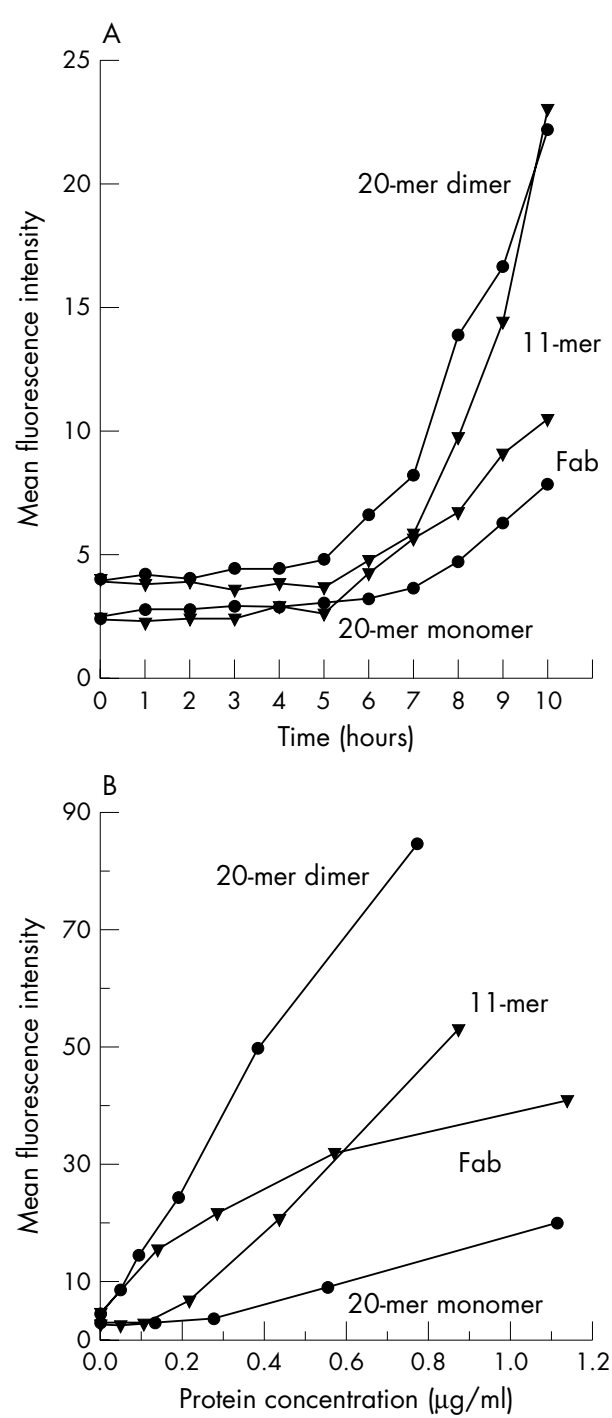

Figure 5 Penetration of different antibody fragment formats across the perfused pig cornea. (A) Mean fluorescence intensity (as measured by flow cytometry on rat thymocytes) of perfusate sampled from representative corneas treated topically with scFv 20-mer monomer and dimer, scFv 11 -mer dimer, and Fab monomer. (B) Titration series of purified protein for each antibody fragment format. Dilutions of purified fragment were tested for reactivity against rat thymocytes by flow cytometry. 
gradually by approximately $30 \%$ over the 10 hour observation time (fig 4).

The perfusate was sampled every hour for detection of binding activity to rat thymocytes. All fragments penetrated through the pig cornea into the artificial anterior chamber (table 2, fig 5A). The time at which antibody fragment was first detected in the perfusate was variable in the range 58 hours (table 2). No significant difference in penetration time was observed between fragment formats, despite the dimeric scFvs and the Fab fragment being twice the size of the monomeric scFv. There was no detectable penetration of whole OX38 IgG into the perfusate over the 10 hour observation time (table 2 ).

In each experiment a titration series of purified protein for each antibody fragment type was performed by flow cytometry (fig 5B). This facilitated comparisons between individual experiments and permitted estimation of the amount of antibody fragment in the perfusate (tables 2 and 3 ). Ten hours after commencement of topical application of eye drops, the mean concentration of protein detected in the perfusate was 0.29 (SD 0.21) $\mu \mathrm{g} / \mathrm{ml}$ (range $0.03-0.80 \mu \mathrm{g} / \mathrm{ml}$ ) across all antibody formats. Although neither the penetration rate nor concentration of antibody fragment that could be achieved in the artificial anterior chamber varied among fragment formats, the penetration of the Fab fragment relative to the concentration of protein applied to the corneal surface was 5-10-fold less than for the engineered antibody fragments (table 3 ).

Endpoint histology of perfused corneas at 10 hours showed intact endothelium and stroma of normal appearance, with generally intact epithelium. However, the most superficial layer of epithelial cells was frequently ragged and in some corneas, intracellular vacuoles were apparent in basal epithelial cells. The presence of vacuoles did not influence the degree of penetration of antibody fragments.

\section{DISCUSSION}

Topical application is a preferred method of administration of drugs to the cornea and anterior segment, because therapeutic concentrations can often be achieved without systemic side effects. We have previously shown that purified scFv will penetrate through the cornea into the anterior chamber of the eye when applied as eye drops in an appropriate formulation. ${ }^{23}$ Such fragments retain binding activity in the anterior chamber.

Chromatographic procedures were developed that allowed separation of highly purified, stable monomeric and dimeric antibody fragments, such that the ocular penetration of monomers of $27 \mathrm{kDa}(20$-mer scFv) and $48 \mathrm{kDa}(\mathrm{Fab})$, and of dimers of $52 \mathrm{kDa}$ (11-mer scFv) and $56 \mathrm{kDa}$ (20-mer scFv) could be compared. Penetration of all formats of antibody fragment through the pig cornea was detected after application of eye drops for 6-7 hours on average, and reached concentrations of approximately $300 \mathrm{ng} / \mathrm{ml}$ after 10 hours. Similar concentrations of monomeric and dimeric scFvs and Fab fragments were achieved in the artificial chamber of perfused corneas, but the Fab showed less efficient penetration compared with other fragments, relative to the concentration of protein in the eye drop. Dimeric forms of scFvs showed improved binding characteristics to target cells expressing a high level of antigen, compared with monomeric forms (fig 5B), and may be desirable for some applications.

The antibody fragments were formulated into eye drops with the addition of two excipients. Sodium caprate has been shown to induce a rapid and reversible loosening of epithelial tight junctions and an enhancement of the paracellular absorption route. ${ }^{33}$ Hydroxypropyl methylcellulose was added to increase the retention time of the aqueous solution of scFv protein and penetration enhancer on the corneal surface. It is probable that the use of this combination of excipients in vitro caused the gradual corneal thickening and the appearance of intracellular vacuoles in some corneas. We have used the same excipients with monomeric scFv in similar experiments on rabbit cornea in vivo. ${ }^{23}$ Corneas remained crystal clear throughout the 12 hour application of eye drops and endpoint histology showed that normal corneal architecture was preserved, suggesting that corneal thickening and vacuoles will not occur clinically. The degree of penetration of scFv in vivo was comparable to that seen in this study. ${ }^{23}$

The action of sodium caprate on the tight junctions of the most superficial epithelial layer is relatively rapid. ${ }^{33}$ The 6 hour lag time before antibody fragments were first detected in the anterior chamber reflects the time for diffusion of protein through the underlying layers of the epithelium, the stroma and the endothelium. The sensitivity threshold of the detection method is a contributing factor. In similar

Table 2 Penetration of antibody fragments through pig corneas mounted in a corneal perfusion chamber

\begin{tabular}{|c|c|c|c|c|}
\hline Antibody fragment & $\begin{array}{l}\text { Molecular weight } \\
\text { (kDa) }\end{array}$ & $\begin{array}{l}\text { Protein concentration in } \\
\text { eye drop }(\mathrm{mg} / \mathrm{ml})\end{array}$ & $\begin{array}{l}\text { Time until detectable } \\
\text { penetration (h) }\end{array}$ & $\begin{array}{l}\text { Protein concentration in } \\
\text { chamber at } 10 \text { hours } \\
(\mu \mathrm{g} / \mathrm{ml})\end{array}$ \\
\hline \multirow[t]{4}{*}{ ScFv 20-mer (monomer) } & 27 & 1.0 & 7 & 0.11 \\
\hline & & 1.0 & 7 & 0.11 \\
\hline & & 1.1 & 6 & 0.50 \\
\hline & & 1.1 & 7 & 0.40 \\
\hline \multirow[t]{5}{*}{ ScFv 20-mer (dimer) } & 56 & 0.8 & 7 & 0.39 \\
\hline & & 0.8 & 5 & 0.80 \\
\hline & & 0.8 & 7 & 0.36 \\
\hline & & 0.8 & 7 & 0.13 \\
\hline & & 0.8 & 6 & 0.18 \\
\hline \multirow[t]{4}{*}{ ScFv 11-mer (dimer) } & 52 & 0.9 & 8 & 0.04 \\
\hline & & 0.9 & 7 & 0.09 \\
\hline & & 0.9 & 6 & 0.48 \\
\hline & & 0.9 & 6 & 0.47 \\
\hline \multirow[t]{5}{*}{ Fab fragment (monomer) } & 48 & 2.3 & 6 & 0.08 \\
\hline & & 2.3 & 7 & 0.03 \\
\hline & & 5.2 & 7 & 0.25 \\
\hline & & 5.2 & 7 & 0.35 \\
\hline & & 5.2 & 7 & 0.45 \\
\hline Monoclonal antibody & $\sim 150$ & $\begin{array}{l}\text { Activity detectable at } \\
1 / 30000 \text { dilution }\end{array}$ & Not detected & Not detected \\
\hline
\end{tabular}


Table 3 Summary of antibody fragment penetration through perfused pig corneas (SD)

\begin{tabular}{llll}
\hline Fragment & No of eyes & Protein in chamber at 10 hours $(\mu \mathrm{g} / \mathrm{ml})$ & $\%$ Penetration* \\
\hline ScFv 20-mer (monomer) & 4 & $0.28(0.20)$ & $0.07(0.05 \%)$ \\
ScFv 20-mer (dimer) & 5 & $0.37(0.26)$ & $0.12(0.09 \%)$ \\
ScFv 11-mer (dimer) & 4 & $0.27(0.24)$ & $0.08(0.07 \%)$ \\
Fab (monomer) & 5 & $0.23(0.18)$ & $0.013(0.008 \%)$ \\
\hline \multirow{2}{*}{ *Amount in the perfusate as percentage of the amount applied to the cornea. } &
\end{tabular}

experiments with de-epithelialised pig corneas, we found that there was a 4 hour lag time before scFv was detected in the anterior chamber. ${ }^{23}$ It is clinically feasible to load the cornea initially with an antibody fragment, using ointment or frequent eye drop application, with subsequent tapering of the frequency of application to maintain the dose.

These findings demonstrate the potential of topically applied antibody fragments with appropriate specificities for treating disorders of the cornea and anterior segment, and the possibility of selecting the most appropriate antibody fragment format for specific therapeutic purposes.

\section{ACKNOWLEDGEMENTS}

The authors thank K Marshall, L Kirk, C-G Chen, A Moisides, A Yusim, D John, B Ferguson, P Karampetsos, and A Meister for expert assistance, and D Gearing, C Panousis, and A Cuthbertson for comments on the manuscript.

\section{Authors' affiliations}

H M Brereton, A Farrall, M Tea, D J Coster, K A Williams, Department of Ophthalmology, Flinders University, Adelaide, Australia S D Taylor, D Hocking, CSL Ltd, Parkville, Victoria, Australia

M A Thiel, Department of Ophthalmology, University of Zurich, Zurich, Switzerland

This work was supported by the National Health and Medical Research Council of Australia, the Ophthalmic Research Institute of Australia and the Flinders Medical Centre Foundation.

Competing interests: $\mathrm{HMB}, \mathrm{AF}, \mathrm{MT}$, DJC and KAW have jointly received funds and reagents for research from CSL Ltd: SDT and DH are employees of CSL Ltd.

Ethical approvals: Experimentation on abattoir eyes was carried out with approval of Flinders University Animal Welfare Committee and conformed to the ARVO statement for the use of animals in ophthalmic and vision research. Experiments involving recombinant DNA were carried out with the approval of the Flinders University/Flinders Medical Centre Biosafety Committee.

\section{REFERENCES}

1 Prausnitz MR, Noonan JS. Permeability of cornea, sclera, and conjunctiva: a literature analysis for drug delivery to the eye. J Pharm Sci 1998;87:1479-88.

2 Tonjum AM. Permeability of horseradish peroxidase in the rabbit corneal epithelium. Acta Ophthalmol 1974;52:650-8.

3 Grass GM, Robinson JR. Mechanisms of corneal drug penetration. II: Ultrastructural analysis of potential pathways for drug movement, J Pharm Sci 1988;77:15-23.

4 Hamalainen KM, Kananen K, Auriola S, et al. Characterization of paracellular and aqueous penetration routes in cornea, conjunctiva, and sclera. Invest Ophthalmol Vis Sci 1997;38:627-34.

5 Lee VH, Carson LW, Takemoto KA. Macromolecular drug absorption in the albino rabbit eye. Int J Pharm 1986;29:43-51.

6 Burstein NL, Anderson JA. Corneal penetration and ocular bioavailability of drugs. J Ocul Pharmacol 1985;1:309-26.

7 Maurice D, Mishima S. Ocular pharmacokinetics. In: Sears M, eds Pharmacology of the Eye. Berlin: Springer-Verlag, 1984:19-116.

8 Stiemke MM, McCartney MD, Cantu-Crouch D, et al. Maturation of the corneal endothelial tight junction. Invest Ophthalmol Vis Sci 1991;32:2757-65.
9 Allansmith $M$, de Ramus $A$, Maurice $D$. The dynamics of $\lg G$ in the cornea Invest Ophthalmol Vis Sci 1979:18:947-55.

10 Maurice DM, Polgar J. Diffusion across the sclera. Exp Eye Res 1977;25:577-82.

11 Olsen TW, Edelhauser HF, Lim Jl, et al. Human scleral permeability. Effects of age, cryotherapy, transscleral diode laser, and surgical thinning. Invest Ophthalmol Vis Sci 1995;36:1893-903.

12 Huang AJ, Tseng SC, Kenyon KR. Paracellular permeability of corneal and conjunctival epithelia. Invest Ophthalmol Vis Sci 1989;30:684-9.

13 Urtti A, Salminen L, Miinalainen O. Systemic absorption of ocular pilocarpine is modified by polymer matrices. Int J Pharm 1985;23:147-61.

14 Chang SC, Lee VH. Nasal and conjunctival contributions to the systemic absorption of topical timolol in the pigmented rabbit: implications in the design of strategies to maximize the ratio of ocular to systemic absorption. J Ocul Pharmacol 1987;3:159-69.

15 Gruntzig J, Nolte S, Schad P, et al. Lymph drainage of the cornea, limbus and conjunctiva. Klin Monatsbl Augenheilkd 1987;190:491-5.

16 Haynes RJ, Tighe PJ, Scott RA, et al. Human conjunctiva contains high endothelial venules that express lymphocyte homing receptors. Exp Eye Res 1999;69:397-403.

17 Schoenwald RD, Deshpande GS, Rethwisch DG, et al. Penetration into the anterior chamber via the conjunctival/scleral pathway. J Ocul Pharmacol Ther 1997;13:41-59.

18 Chien DS, Homsy JJ, Gluchowski C, et al. Corneal and conjunctival/scleral penetration of p-aminoclonidine, AGN 190342, and clonidine in rabbit eyes. Curr Eye Res 1990;9:1051-9.

19 Ahmed I, Patton TF. Importance of the noncorneal absorption route in topical ophthalmic drug delivery. Invest Ophthalmol Vis Sci 1985;26:584-7.

20 Hudson PJ. Recombinant antibody fragments. Curr Opin Biotechnol 1998;9:395-402.

21 Larson SM, El-Shirbiny AM, Divgi C, et al. Single chain antigen binding protein (sFv CC49). First human studies in colorectal carcinoma metastatic to liver. Cancer 1997;80:2458-68.

22 Yokota T, Milenic DE, Whitlow M, et al. Rapid tumor penetration of a singlechain Fv and comparison with other immunoglobulin forms. Cancer Res 1992:52:3402-8.

23 Thiel MA, Coster DJ, Standfield SD, et al. Penetration of engineered antibody fragments into the eye. Clin Exp Immunol 2002;128:67-74.

24 Jefferies WA, Green JR, Williams AF. Authentic T helper CD4 (W3/25) antigen on rat peritoneal macrophages. J Exp Med 1985;162:117-27.

25 Krebber A, Bornhauser S, Burmester J, et al. Reliable cloning of functional antibody variable domains from hybridomas and spleen cell repertoires employing a reengineered phage display system. J Immunol Methods 1997;201:35-55.

26 Plückthun A, Krebber A, Krebber C, et al. Producing antibodies in Escherichia coli: from PCR to fermentation. In: McCafferty J, Hoogenboom HR, Chiswell DJ, eds. Antibody engineering. A practical approach. Oxford: Oxford University Press, 1996:203-52.

27 Mavrangelos C, Thiel M, Adamson PJ, et al. Increased yield and activity of soluble single-chain antibody fragments by combining high level expression and the Skp periplasmic chaperone. Prot Express Purif 2001;23:289-95.

28 Kang Y, Luo R. Chromatographic removal of endotoxin from hemoglobin preparations. Effects of solution conditions on endotoxin removal efficiency and protein recovery. J Chromatogr A 1998;809:13-20.

29 Goding J. Purification, fragmentation and isotopic labelling. In: Monoclonal antibodies: principles and practice, production and application of monoclonal antibodies in cell biology, biochemistry and immunology. London: Academic Press, 1996:126-30.

30 Coulter A, Harris R. Simplified preparation of rabbit Fab fragments. J Immunol Methods 1983;59:199-203.

31 Thiel MA, Morlet N, Schulz D, et al. A simple corneal perfusion chamber for drug penetration and toxicity studies. Br J Ophthalmol 2001;85:450-3.

32 Zola H, Neoh SH, Mantzioris BX, et al. Detection by immunofluorescence of surface molecules present in low copy numbers. High sensitivity staining and calibration of flow cytometer. J Immunol Methods 1990; 135:247-55.

33 Soderholm JD, Oman H, Blomquist L, et al. Reversible increase in tight junction permeability to macromolecules in rat ileal mucosa in vitro by sodium caprate, a constituent of milk fat. Dig Dis Sci 1998;43:1547-52. 